Man and Nature

MAN AND NATURE

L'homme et la nature

L'HOMME ET LA NATURE

\title{
Polemical Intent and Rhetorical Style in d'Alembert's Éloges historiques
}

\section{Dennis F. Essar}

Volume 1, 1982

URI : https://id.erudit.org/iderudit/1011789ar

DOI : https://doi.org/10.7202/1011789ar

Aller au sommaire du numéro

Éditeur(s)

Canadian Society for Eighteenth-Century Studies / Société canadienne d'étude du dix-huitième siècle

ISSN

0824-3298 (imprimé)

1927-8810 (numérique)

Découvrir la revue

Citer cet article

Essar, D. F. (1982). Polemical Intent and Rhetorical Style in d'Alembert's Éloges historiques. Man and Nature / L'homme et la nature, 1, 31-39.

https://doi.org/10.7202/1011789ar

Copyright (C Canadian Society for Eighteenth-Century Studies / Sociéte canadienne d'étude du dix-huitième siècle, 1982
Ce document est protégé par la loi sur le droit d'auteur. L'utilisation des services d'Érudit (y compris la reproduction) est assujettie à sa politique d'utilisation que vous pouvez consulter en ligne.

https://apropos.erudit.org/fr/usagers/politique-dutilisation/ 


\section{Polemical Intent and Rhetorical Style in d'Alembert's Éloges historiques}

In his biography of d'Alembert, Ronald Grimsley quotes from LouisSébastien Mercier's Tableau de Paris the following description of a typical public meeting of the Académie française on August 25, the feast day of Saint Louis:

M. d'Alembert est heureux le jour de la Saint-Louis; il va, il vient, il ouvre les tribunes, il commande aux Suisses, il a sous ses ordres deux abbés panégyristes; il place les dames à panaches, il préside les quarante immortels. Assis enfin en haut de la longue table que couvre un tapis vert, il ouvre la séance et distribue des prospectus; puis il donne la médaille immortalisante à son protégé, qui deviendra un petit ingrat.

Il lit ensuite un éloge parfois malin, où il a semé de petites vérités modestes, avec une prudence, un sel, un enjouement qui divertissent l'assemblée. Il ne dit presque rien, mais on voit ce qu'il voudrait dire; on l'entend dans ses petites allusions, et l'on bat des mains. Tout cela ne signifiera absolument rien dans vingt ans. ${ }^{1}$

This description, one commentary among the many we possess on the subject of d'Alembert and his reading of the éloges, is particularly provocative. It emphasizes that d'Alembert is performing for a public, a receptive and wellinformed body of sympathetic admirers. And second, it underlines the important distinction between what is said and what is meant, between literal text and intended message. A perceptible tension arises in the mind of the listener, who appreciates the separation of form and meaning, and who readily compares one with the other.

D'Alembert was elected to the Académie in 1754, and from the beginning his presence in that body was of great political significance. When in 1772 he succeeded Duclos as secrétaire perpétuel, another opportunity was presented to the philosophic party for the dissemination of its thought and ideals. Although some éloges historiques, as d'Alembert called them, had already been written before that time, ${ }^{2}$ most were composed after 1772 . D'Alembert, as secrétaire perpétuel, set himself the task of continuing the history of the Académie by writing the éloge of each academician who had died from 1700 onwards. In so doing he was following the example of others before him. ${ }^{3}$

Of the ninety éloges historiques included in the 1820-1821 Belin edition of d'Alembert's Oeuvres complètes, ${ }^{4}$ four are not about academicians, ${ }^{5}$ and are 
not typical of the genre. Of the remaining 86 , fifteen were read in the Académie once (one of these was read after d'Alembert's death ${ }^{6}$ ), and two were read twice. ${ }^{7}$ Those pieces that had been read in the Académie excited the greatest interest, of course, and at least two of them ${ }^{8}$ were published almost immediately in the Mercure. The thirteen éloges that had been read up to 1779 were published, together with some incidental pieces that d'Alembert had also presented to the Académie, in a volume of that year entitled Eloges lus dans les séances publiques de l'Académie française. This volume in turn was reprinted as the first of six in the posthumous ${ }^{9}$ collection entitled Histoire des membres de l'Académie française, edited by Condorcet, and published in 1785 and 1787. The last five volumes of this collection include the numerous pieces that were never read, as well as the voluminous notes to all the éloges. The conception of these texts that obtains, then, from the tidy Belin edition, is somewhat misleading. In reality the texts were brought to the attention of the public by various means and over a considerable period of time.

A more important result of this publication history is that d'Alembert the narrator, the historian, the polemicist, appeared to the public in a variety of guises, according to the mode in which the polemic content was delivered. The first and most important of these personae was that of the author, the well-known philosophe and Encyclopaedist, physically present before the wonderfully cultivated and in part hostile audience in the Académie. The éloges presented in this theatre are among the best from the point of view of sustained interest, stylistic variety, and polemic impact. Here the most sparkling and brilliant d'Alembert is revealed. However, the narrator as he presents himself to the reading public, in the éloges that were communicated only in the printed form, is less gracious, less witty than his more visible counterpart. And in the vast notes that d'Alembert supplied, the narrator is even more frank, more brutal. Irony is much rarer here, and less subtle when it does occur. The author is concerned with communicating facts and opinion that would be either distracting or provocative in the body of the text. Thus we may conclude that d'Alembert intended, in the éloges that received a reading in the Académie, to conceal more effectively the polemicist behind the mask of the public eulogist. A greater ironic tension is thus created in the public éloges, by the opposing forces of form and real meaning, a tension that results in a delighted clapping of the hands among the audience, as we have seen, and a glowing appreciation for the author's finesse.

In the Encyclopédie article "Eloges académiques", d'Alembert places limits on the degree to which truth, in these texts, can be revealed:

Ces éloges, étant historiques, sont proprement des mémoires pour servir à l'histoire des lettres. La vérité doit donc en faire le caractère principal. On doit néanmoins l'adoucir, ou même la taire quelquefois, parce que c'est un éloge, et non une satire, que l'on doit faire; mais il ne faut jamais la déguiser ni l'altérer. ${ }^{10}$ 
Truth, in this description, is conceived in a simplistic way to be something concrete, recognizable, accessible; there is a fundamental, obvious difference between truth and untruth. But does not d'Alembert's description of the éloge académique contain contradictory elements? While he preaches the inherent value of truth, does he not recognize the advisability, and perhaps even the necessity, of softening it, of presenting it in a way other than in its most obvious, limpid forms? In other words is not d'Alembert suggesting that what he claims should be truth, may be in fact, either by commission or by omission, untruth?

In the éloges historiques we witness just such a manipulation of fact. But d'Alembert takes these liberties for polemic reasons, rather than merely to protect the subject's good name. To be sure, one aim of the text is to present a description of past events, of historical personnages, of moods and attitudes, by means of a discussion of the particular academician in question. But in fact d'Alembert's preponderant aim in the éloges is to further the cause of the philosophic party, to use the Académie, and later on the published Histoire, to put forward the basic platform of the group he is representing. In short, the narrator, at the various levels we have seen, sets out a dialogue between past and present, in the form of a description of historical events revealed and interpreted by a not disinterested commentator. The life of virtually every academician supplies to d'Alembert numerous occasions to reiterate articles of the philosophic creed, to portray, from a partisan point of view, a series of events stretching over a particular period of time. Thus, the vision of the past that we form from these texts is locked into a particular vision of the present, a vision so typical and indeed almost characteristic of the philosophes, in which a long-term meliorist optimism is paradoxically tied to general metaphysical scepticism. The past is made to exist as a function of a slow but inexorable process by which better days are in a perpetual state of becoming, and by which old gods will be made to die.

But what is the more precise nature of this manipulation of historical fact? First of all, in the éloges, facts are chosen selectively. As d'Alembert advises, again in "Eloges académiques",

. . . si [les ouvrages de l'académicien] ne fournissent absolument rien à dire, que faire alors? Se taire. Et si par un malheur très rare, la conduite a déshonoré les ouvrages, quel parti prendre? Louer les ouvrages. ${ }^{11}$

However, if facts can be hidden, or neglected, they can also be modified. Such is the case with the basically simplistic historical vision of d'Alembert in the éloges, in which the Jesuits are seen only as manipulators, in which Louis XIV does nothing but heed corrupt advisers, in which Fénelon appears not as a quiétiste, but only as the author of the Télémaque, and in which Bossuet is considered as a religious extremist rather than the firm defender of Gallican liberties. Such carefully chosen and weighted historical views are then placed in an attentively planned and executed narrative. Indeed, what determines the nature of the text is its resultant emotional and propagandistic impact, not its historical objectivity or its universal utility. What is purported to be fact is in reality caricature. Just as a cartoonist presents an abstraction of his subject, so individuals, personalities, and reactions are portrayed by 
d'Alembert as functions of a polemic aim. The past is interpreted in a way complementary to the philosophic vision of a new, eternal, universal system of values, in which truth, tolerance, justice and enlightenment are upheld.

Fact becomes caricature in the éloges in a variety of ways. First of all, and this is perhaps the most important single rhetorical device in the whole body of the éloges, the historical past is depicted in a simplistic fashion as a series of conflicts between forces that may be described bluntly as good and evil. The past is, to a great extent, revealed as the dwelling place of the villainous. But through the years, evil presences have begun to recede. Although the victory is far from complete, the evil elements of the status quo are seen to be dying out, yielding to the forces of progress, in other words to the forces of philosophie. On the other hand, d'Alembert draws our attention to the appearance, in the past, of the humble beginnings of the quest for truth and enlightenment, and describes the process by which progressive ideas have been and are being pushed toward a final triumph. This conception is of course very reminiscent of the idea of historical process revealed in the Discours préliminaire.

In his description of villainy in the historical past, d'Alembert sets out a number of discernible categories, for each of which there is an opposing category on the side of good. First, and most obvious, is the presence of perfidious individuals, for whom d'Alembert does not hide his complete contempt. Chief among these are well-known Jesuits, ${ }^{12}$ such as La Chaise and Le Tellier, who are also portrayed as notorious manipulators. Jussieu is shown as a repugnant fanatic. Molinos is the originator of the absurd quiétisme, and Philip II is a perpetrator of "superstition barbare" (OC III, 88). Best known of this group is of course Bossuet, who, despite his Gallican sympathies, passes into the ranks of the disgraciés because of his tepid opposition to the persecution of protestants under Louis XIV, and more importantly because of his struggle with Fénelon.

Set against these villains are d'Alembert's heroes: Fénelon, of course, and Descartes, at least insofar as he represented a renewal of philosophic enquiry, Molière, Fontenelle, Helvétius, and Voltaire. Even the fervent Pascal is seen as a philosophic hero because of the Provinciales.

Among those customs and tastes castigated by d'Alembert, we find, for example, the penchant for writing Latin poetry. This is very often portrayed as the pastime of musty clerics. Dull, plodding erudition, similarly because of its link with Biblical studies, is frequently associated with the cast of mind that admits religious intolerance and fanaticism. Ecclesiastics and nobles are too often ruled by a villainous pride, as in the case of the grotesque Clermont-Tonnerre. And finally, courtly flattery ${ }^{13}$ is responsible for a multitude of evils, in particular as it influenced Louis XIV, who appears in the éloges as a very gullible, but otherwise quite acceptable sovereign.

Villainous institutions mentioned by d'Alembert include the court, which deforms and reduces individual merit, and monasticism, which ensnares the young and binds them to a useless, unproductive existence. But chief among the institutions criticized is of course the Society of Jesus. In all domains the Jesuits are revealed as the complete opposites of the philosophes; their active malfeasance is responsible for untold suffering through the encouragement of 
fanaticism and resultant persecution.

Among those institutions that d'Alembert feels are unjustly maligned, and that possess a nature that is fundamentally good, are the theatre, ${ }^{14}$ which he claims teaches virtue and good citizenship, ${ }^{15}$ and the Académie itself, which must resist the influence of authority and retain its precious independence. Both the theatre and the Académie were of course seen by d'Alembert and by many others, it should be noted, as areas in which philosophie could most effectively exert its influence.

Ultramontanism is portrayed as a vicious political idea, the work of the Jesuits, designed to strengthen the power of the papacy at the direct expense of the central French government. Gallicanism, therefore, is consistently shown as a good and just policy. It is to be noted, however, that Bossuet's important rôle in the debate over Gallicanism is to a certain extent ignored by d'Alembert. Although the part Bossuet played is mentioned, other factors, as we have seen, do not allow him to be accorded the credit that is his due. Ultramontanism, because of its link with the Jesuits, is shown to be an aberration in the same class as religious intolerance and the sadism that characterized religious persecutions of the age of Louis XIV. D'Alembert's feelings about ultramontanism are no doubt strongly influenced by his hatred of the Jesuits, but it is clear that in this domain a most unphilosophic protonationalism also plays its part.

Theology and scholastic philosophy are of course described by d'Alembert as frivolous, unprofitable exercises. But he spares no pain to praise the study of mathematics and science, particularly in the very early "Eloge de Bernoulli". ${ }^{16}$

Consistently, then, in the éloges, d'Alembert creates balanced, opposing pairs of abstractions, or caricatures, whose express purpose is to call to the mind of the reader or listener, those elements of the philosophic creed that have been so often repeated in the past. There is little that is strikingly new, it must be said, in the list of these elements one is led to compile for oneself while reading the éloges. But d'Alembert knew as well as Voltaire and Diderot, and all the other propagandists of whatever stripe in that age or in any other, that the secret of persuasion is repetition of recognizable symbols or simple ideas at a level and in a style that will be appreciated by the persons to whom the discourse is directed. The aim of these éloges, then, is to convince, to amuse, and not to provide accurate history.

Although I have dwelt upon the use of caricature in the éloges, it is not the only form of distortion that appears in these texts. At times, in his praise of nobility, royalty, legal authority and religion, d'Alembert is telling what we know are outright lies. ${ }^{17}$ At other times, he allows himself to offer fulsome praise of an academician's social status and political connections, without offering any valid reasons why the individual should have been elected to the Académie in the first place. The best example of this form of sustained irony is the article on François de Clermont-Tonnerre, an article that, incidentally, is entitled "Apologie" rather than "Eloge". Clermont-Tonnerre's outstanding weakness, the one singled out for ridicule by d'Alembert, is his pride, which predictably is always described in such terms as "une fierté estimable et bien placée" (OC II, 175). D'Alembert mentions a number of times in the text the 
"ironie perpétuelle" (OC II, 174, for example) that marked the discours de réception delivered when Clermont-Tonnerre was admitted to the Académie; such is d'Alembert's way of suggesting that his own text is of a similar nature.

But perhaps one of the most devastating forms of criticism, when one bears in mind the exceedingly sophisticated public for whom the éloges were intended, is silence. We must constantly remind ourselves, as no doubt d'Alembert's readers and listeners did, of what he is not saying. The most evident lack in the 1200 pages of text of the éloges, is that of references to Jean-Jacques Rousseau, who, it would seem, is thus pointed out as one who is no longer associated with the cause, whose political value is reduced to nothing.

Another technique used by d'Alembert to strengthen his philosophic message, is to adapt the tone of his éloge to the subject he is discussing. ${ }^{18}$ Some éloges contain sustained passages explaining a particular theoretical or doctrinal point. Such passages are written in a measured, sober style. ${ }^{19}$ In almost every éloge, similarly solemn passages appear in which lip service is paid to the usual academic commonplaces of independence, equality, and mutual respect. Bitter, sardonic sarcasm is reserved almost entirely for the notes, and is not common. In contrast to such seriousness, however, many éloges are marked by a tone of open, rollicking good humour. The "Eloge du président Rose" (OC II, 161-169), for example, is rather familiar and conversational. D'Alembert seems, in such pieces as the apologie of Clermont-Tonnerre, and especially in the éloges of two remarkable originaux, the abbé de Saint-Pierre and the abbé de Choisy, to release completely the combination of rire fin and rire polisson for which he was famous. No reader of the éloge of the fatuous Gaspard Abeille (OC II, 516-522), can suppress a smile when he encounters the suggestion that this abbé "savait donner [à ses plaisanteries] une forme piquante" (p. 516), and when he reads at least nineteen times in six pages the ridiculous appellation, "abbé Abeille"!

Finally, d'Alembert distributes throughout the éloges certain linguistic sign-posts that help the reader or listener to perceive effortlessly the author's attitude in a particular matter. The term philosophe is used in a variety of ways, for example, ${ }^{20}$ but in general the words philosophe, philosophie and philosophique are all used to denote individuals, qualities, attitudes and ideas that elicit d'Alembert's wholehearted approval. ${ }^{21}$ Similarly, the metaphoric use of lumière suggests at the same time the source and end product of philosophie.

Rhetoric had of course long been regarded, by d'Alembert's time, as a set of techniques whose admissibility was to some extent morally questionable. Truth, to use a term favoured by d'Alembert, is disguised in the rhetorical text, which reveals as it were only an obfuscated projection of the originally intended meaning, and which ironically masks the real matter of the author's thought. ${ }^{22}$ In the Discours préliminaire, d'Alembert presents this sort of 
criticism. First of all, he suggests, eloquence is defined as the ability to communicate emotion:

Les hommes, en se communiquant leurs idées, cherchent aussi à communiquer leurs passions. C'est par l'éloquence qu'ils y parviennent. Faite pour parler au sentiment, comme la logique et la grammaire parlent à l'esprit, elle impose silence à la raison même . . . . ${ }^{23}$

Eloquence, however, is quite distinct from rhetorical facility:

A l'égard de ces puérilités pédantesques qu'on a honorées du nom de rhétorique, ou plutôt qui n'ont servi qu'à rendre ce nom ridicule, et qui sont à l'art oratoire ce que la scolastique est à la vraie philosophie, elles ne sont propres qu'à donner de l'éloquence l'idée la plus fausse et la plus barbare. $^{24}$

True eloquence thus proceeds from the heart, so to speak, rather than the head. Any attempt at rational control of the text inevitably fails: "Tant pis pour tout orateur qui fait avec réflexion et avec dessein une métonymie, une catachrèse, et d'autres figures semblables." ${ }^{25}$ D'Alembert would thus have us believe that the eloquent orator expresses his intended message with complete natural sincerity and with effortless facility. His message is not obscured by rhetorical diversions.

But in his letters to Frederick the Great, d'Alembert openly admits that in the composition of the éloges he exercises just such a rational control over the text. For example, on 14 August 1772 he writes:

Je vais cependant essayer la continuation de l'histoire de l'Académie française; mais combien de peine il faudra que je me donne pour ne pas dire ma pensée! Heureux même si, en la cachant, je puis au moins la laisser entrevoir. (OC V, 326)

And on 9 April 1773, he confesses that writing these éloges requires wearying effort: "quand je pense que j'ai d'un côté de mauvais auteurs à disséquer, et de l'autre de plats censeurs à satisfaire, la plume me tombe des mains presque à chaque instant" (OC V, 336). Such declarations show that the creation of these texts is by no means a natural, easy process. And, as we have seen, throughout the éloges historiques, evidence of a rhetorical consciousness, that is to say a tendency to express thoughts through the use of discernible and classifiable rhetorical techniques, can readily be found.

D'Alembert, along with other members of the philosophic party, and especially the contributors to the Encyclopédie, in general strongly favoured the theories of universal grammar propounded by the Port Royal grammarians. Universal grammar theory is seen as the key to understanding the true nature of language and thought, by revealing deep structures of which surface forms ought to be the unretouched model. D'Alembert's ideas about eloquence are similar to the notion of universal grammar, in that both theories suggest the ideal of a sort of transparent language, in which the true intentions of the author are openly revealed. The philosophe, whose language is thus indirectly claimed to proceed untrammeled from the depths of his consciousness, is proposed as a being of unquestionable sincerity, incapable of 
machination or duplicity. D'Alembert's theory of eloquence, like universal grammar theory, contains more than a hint of ideological bias.

To be sure, there were pragmatic reasons for d'Alembert to mask his true thoughts. As a matter of convention he must avoid criticism of the Académie, and as well, as he notes himself, he has censors to satisfy.

But there is another, stronger reason, as I have suggested, for thus modifying, supplementing, and disguising historical fact: d'Alembert wishes above all to convince his readers and listeners of the righteousness of his cause, to convert them to his point of view, to pull them into the sphere of influence of his party. If it is necessary to project a rhetorically determined history in order to further his cause, then he is not unwilling to do so. And theoretical pronouncements condemning rhetorical technique as misleading, only lend force to his own position as a historian, as a narrator, and as an oracle.

Thus, in the final analysis, we may perceive a fundamental contradiction in d'Alembert's claims. He presents untruth as truth; he condemns rhetorical devices and yet indulges in their use; he sets up moral and social principles that he claims to be of universl and eternal value, when in truth they are the principles of the pressure group he represents. Politics is thus never far from the mobile centre of d'Alembert's preoccupations. And for that reason it is exceedingly dangerous for us to accept the portraits that he communicates in the éloges of himself, of his circle, of the society of his time, and of the subjects of these texts, without taking into account the polemic importance of each element of the whole.

Dennis F. Essar

Brandon University

\section{Notes}

L.-S. Mercier, Tableau de Paris (Amsterdam, 1782-1788), VIII (1783), 27-28. Quoted in English by R. Grimsley in Jean d'Alembert (1717-83) (Oxford: Clarendon, 1963), p. 93. Spelling and punctuation have been modernized in all quotations.

2 The éloges of Montesquieu, Du Marsais and the abbé Mallet had been published in the Encyclopédie. Those of Terrasson and Jean Bernoulli had also already been composed but had not been given their final form.

${ }^{3}$ D'Olivet and Duclos in the Académie française, and Fontenelle in the Académie des sciences.

${ }^{4} 5$ vols. Subsequent references to this edition will be noted in parentheses after the text as OC, together with volume and page number.

5 The éloges of Bernoulli, Mallet, Du Marsais and George Keith.

6 The éloge of Marivaux.

7 The éloges of Fénelon and Boileau.

8 The éloges of Fénelon and La Motte.

9 D'Alembert died in 1783.

${ }^{10}$ Encyclopédie, V (1755), 527.

1 Encyclopédie, V, 528.

12 It must be remembered that most of the éloges were written after the suppression in France of the Society of Jesus in 1767. D'Alembert's important rôle in the battle for expulsion was of course well known.

${ }^{13}$ Flattery is usually spoken of in the éloges as encens; the ecclesiastical resonance of this metaphor was no doubt pleasing to d'Alembert. 
${ }^{14}$ D'Alembert had a remarkable capacity to bear grudges. One is reminded not infrequently in the éloges of the great quarrel over d'Alembert's views on the theatre as revealed in the Encyclopédie article "Genève" in 1757.

is See especially the "Eloge de Nivelle de La Chaussée," OC III, 387-403.

${ }^{16}$ OC III, 338-360. This éloge was first published in the Mercure in 1748 and was later expanded. See M. Wachs, "A Study of d'Alembert's Histoire des membres de l'Académie française" (unpublished dissertation, University of Wisconsin, 1958), pp. 38, 320.

17 An example is when he protests that it is necessary to have high-born members of the Académie, even if they are otherwise undeserving, to give the assembly stature and to acquire for it the respect of the public (see OC II, 480). D'Alembert contradicts this statement throughout the éloges, especially in the notes.

${ }^{18}$ See M. Wachs, pp. 58-60, for pertinent further comment on this aspect of d'Alembert's techniques.

19 See for example the "Eloge de La Motte" (OC III, 121-174). Other examples are the éloges of Montesquieu, Bernoulli, and Du Marsais, but these are not typical (see note 2).

${ }^{20}$ See Peter E. Nitchie, "The Eloges in the Encyclopédie: genre or strategem?", Kentucky Romance Quarterly, XXIII (1976), 506.

${ }^{21}$ D'Alembert even goes so far as to insert this word surreptitiously into a passage he claims is quoted from scripture: "[Daniel] rit en philosophe, de la crédulité du prince et de la fourberie des prêtres, et empoisonna le serpent" (OC III, 489). The event referred to is described in one of the apocryphal chapters of Daniel; however the chapter does not contain this precise description, and no word that could be construed as the equivalent of philosophe is to be found therein.

${ }^{22}$ Two useful recent studies of these questions are Pierre Kuentz, "Le 'rhétorique' ou la mise à l'écart," Communications, XVI (1970), 143-157, and Ulrich Ricken, Grammaire et philosophie au siècle des lumières (Villeneuve-d'Ascq: Publications de l'Université de Lille III, 1978).

${ }^{23}$ Encyclopédie, I (1751), x. The whole question of d'Alembert's anti-rhetoric as revealed in the Discours préliminaire has been examined by Ralph S. Pomeroy in "Locke, Alembert, and the anti-rhetoric of the "Enlightenment," Studies on Voltaire and the Eighteenth Century, CLIV (1976), 1657-1675.

${ }^{24}$ Ibid.

${ }^{25}$ Encyclopédie, article "Eloquence," V (1755), 526. 